\title{
20. CLAY MINERALOGY OF THE PLIOCENE AND PLEISTOCENE OF HOLE 653A, WESTERN TYRRHENIAN SEA (ODP LEG 107) ${ }^{1}$
}

\author{
J. P. de Visser ${ }^{2}$ and H. Chamley ${ }^{3}$
}

\begin{abstract}
X-ray diffraction analyses were performed on 139 samples from the marine Pliocene and Pleistocene of ODP Hole $653 \mathrm{~A}$ in the Tyrrhenian Sea. The quantitative clay mineral record, calibrated to the numerical time scale, is indicative of a succession of environmental changes on the peri-Tyrrhenian continents. A large sedimentary supply of recycled material is recognized in the earliest Pliocene. From 4.6 to $3.4 \mathrm{Ma}$ the climate may have become progressively more arid, but the clay mineral signal might also indicate increasing erosion due to tectonic uplift of the source areas. At about $1.6 \mathrm{Ma}$ accelerated uplift/emergence can be recognized, followed by a shift toward a cooler climate in the early Pleistocene. Widespread volcanic activity on the Tyrrhenian side of the Apennines, starting at about $1.0 \mathrm{Ma}$, might be recognizable in the smectite pattern.
\end{abstract}

\section{INTRODUCTION}

In the Pliocene to Pleistocene sequence of Site 132, which was recovered from the Tyrrhenian Basin during Leg 13 of the Deep Sea Drilling Project (Ryan, Hsü, et al., 1973), nine clay mineral zones were recognized (Chamley, 1975a, 1983; Fig. 1). The lowermost Pliocene zones 1 and 2 of the high resolution clay mineral record were considered to reflect the aftermath of the radical changes in erosional and sedimentary conditions associated with the termination of the Messinian salinity crisis. The composition of the clay mineral associations in these two zones could not be related to specific climatic conditions. The successive zones 3 to 9 were distinguished on the basis of fluctuations mainly in illite crystallinity but also in the relative abundance of smectite. Changes in the degree of humidity and temperature were reconstructed for the peri-Tyrrhenian regions (Fig. 1; Chamley, 1975a, 1983).

The purpose of restudying the clay mineralogy of a parallel sedimentary sequence of ODP Hole 653A, located half a mile northeast of DSDP Site 132 (Shipboard Scientific Party, 1987; Fig. 2), is twofold. Firstly, samples taken from Hole 653A allow us to draw a first-hand comparison between clay mineralogical data and new lithological and faunal data and interpretations from ODP Leg 107. Secondly, in the future, the clay mineral record of this site will be compared with time-equivalent and identically analyzed clay mineral records for marine deposits in southern Italy (de Visser, in prep.). The present paper gives the results of the X-ray diffraction analyses of 139 samples taken at regularly spaced intervals from the Pliocene and Pleistocene of Hole $653 \mathrm{~A}$ (Cores 1-24). Our main purpose is to investigate whether the earlier inferred climatic evolution during the time interval can be substantiated by a mathematical analysis of the new, quantitative clay mineral data. Particular attention will be paid to the relations between the different clay minerals and to their possible sources and source areas.

\section{METHODS}

A Philips PW 1730 diffractometer equipped with a proportional counter was used for X-ray diffraction of the samples ( $\mathrm{CuK} \alpha$ radiation,

\footnotetext{
${ }^{1}$ Kastens, K. A., Mascle, J., et al., 1990. Proc. ODP, Sci. Results, 107: College Station, TX (Ocean Drilling Program).

2 Department of Geology, Institute of Earth Sciences, University of Utrecht, Budapestlaan 4, 3584 CD Utrecht, The Netherlands.

${ }^{3}$ Laboratoire de Dynamique Sédimentaire et Structurale, U.F.R. des Sciences de la Terre, Université des Sciences et Techniques de Lille, 59655 Villeneuve d'Ascq Cedex, France.
}

$40 \mathrm{kV}, 25 \mathrm{~mA}, \mathrm{Ni}$ filter, $1^{\circ}$ divergence and antiscatter slit, $0.1^{\circ}$ receiving slit, counter voltage $1820 \mathrm{~V})$. After decalcification $(0.2 \mathrm{~N} \mathrm{HCl})$ and deflocculation ( $2500 \mathrm{rev} / \mathrm{min}$ ) of the smaller than $63 \mu \mathrm{m}$ size fraction, the analyses were performed on oriented pastes of the smaller than $2 \mu \mathrm{m}$ size fraction (obtained by decanting). Two oriented pastes of each sample were scanned: one in its natural state (not treated any further after centrifugation) and after being glycolated (exposed under vacuum to ethylene glycol for $12 \mathrm{hr}$ ) and the other after being heated (at $490^{\circ} \mathrm{C}$ for $2 \mathrm{hr}$ ). Pastes in a natural state were scanned from $2.5^{\circ}$ to $28.5^{\circ} 2 \theta$; after glycolation and heating, the sector of scanning was limited so that it ranged only from $2.5^{\circ}$ to $14.5^{\circ} 2 \theta$.

Relative proportions of clay minerals and semi-quantitative abundances of accessory minerals were estimated from reflection intensities on the X-ray diffraction patterns. Clay minerals were quantified on the basis of peak-heights on the X-ray traces of natural, glycolated, and heated slides. Following the methods described by Holtzapffel (1985), differences in peak-sharpness were taken into account. Since no internal standards were used and no comparison with standard clay mineral mixtures was made, the accuracy of the analyses is not known. The relative error is estimated to be less than $5 \%$. Chlorite/kaolinite and chlorite/illite peak-height ratios were calculated from measurements on diffractograms of natural slides; palygorskite/illite and smectite/illite peak-height ratios were recorded after glycolation. Another ratio which we consider is the abundance of interstratified layers relative to the sum of the chlorite and illite percentages. The breadth of the $10 \AA$ peak at half-height on the X-ray diagrams of the glycolated slides was measured in order to trace variations in illite crystallinity (Kübler, 1966).

For the chronology of Hole $653 \mathrm{~A}$ we used the following age-calibrated events:

$1.10 \mathrm{Ma} G$. cariacoensis- $G$. truncatulinoides excelsa zonal boundary $1.60 \mathrm{Ma}$ MPI6-G. cariacoensis zonal boundary

$2.05 \mathrm{Ma}$ first influx of $G$. truncatulinoides

3.06 Ma MPI4-MPl5 zonal boundary

3.60 Ma MPI3-MPI4 zonal boundary

4.10 Ma MPI2-MPI3 zonal boundary

4.71 Ma MPI1-MPI2 zonal boundary

4.86 Ma Miocene-Pliocene boundary

Most of these ages are derived from sediment accumulation curves for Holes 652A and 654A of Leg 107, for which holes a magnetostratigraphy is available (Kastens, Mascle, et al., 1987). The details of the agecalibrations are in the Appendix.

\section{RESULTS \\ Quantitative Data}

Smectite is the most abundant mineral, with values ranging from $15 \%$ to $60 \%$ of the clay fraction (Fig. 3). Illite is the sec- 


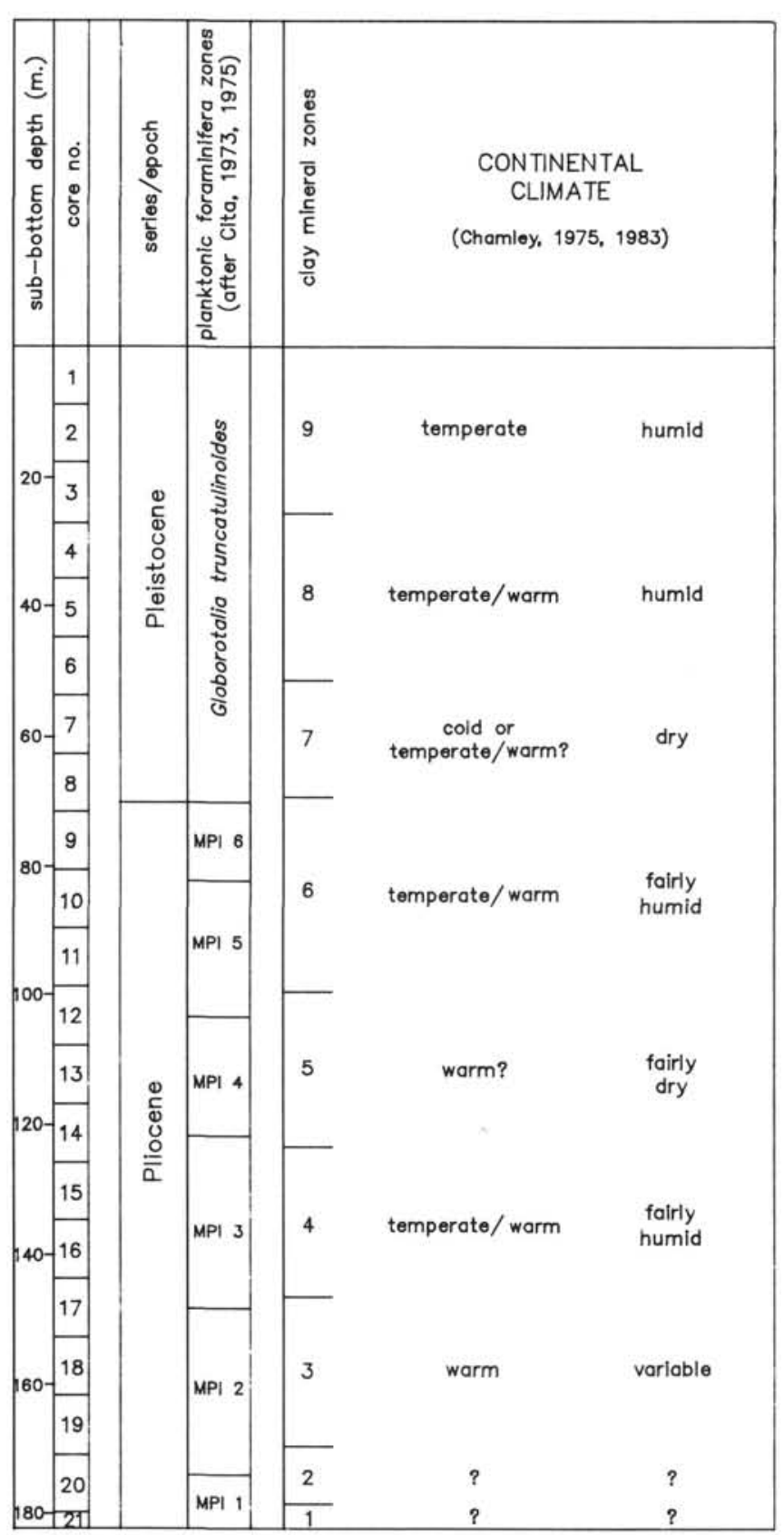

Figure 1. Clay mineral zones in the Pliocene-Pleistocene of Site 132 of DSDP Leg 13 and climatic evolution as proposed by Chamley (1975a, 1983).

ond most abundant component, with percentages varying between $15 \%$ and $45 \%$. Kaolinite varies between $10 \%$ and $25 \%$, chlorite between $5 \%$ and $15 \%$. Palygorskite, chlorite-smectite irregular-mixed-layers, illite-smectite irregular-mixed-layers, and sepiolite are the least abundant clay minerals. Their percentages vary from $0 \%$ to $15 \%$, from traces to $10 \%$, from $0 \%$ to $10 \%$, and from $0 \%$ to $5 \%$, respectively. Sepiolite had not been recorded in the interpretation of the diffractograms of the earlier DSDP Site 132. Nonclay minerals include quartz, feldspar, amphibole, and goethite. The iron-oxyhydroxide goethite is very abundant in the rubiginous, lowermost Pliocene subunit Ic. The diffractograms of eight samples, including the samples from volcanic ash layers and sapropelic layers, were of insufficient quality and not suitable for quantification.

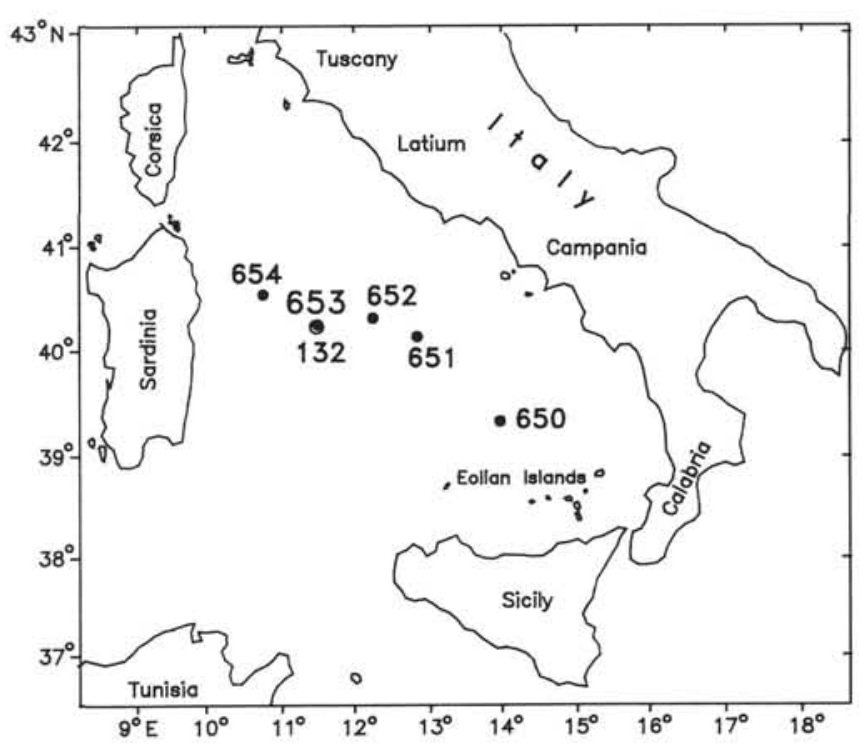

Figure 2. Sketch map of the Tyrrhenian Sea showing the location of DSDP Site 132 and ODP Holes 650A, 651A, 652A, 653A, and 654A.

The most conspicuous element of the clay mineral distribution in Hole $653 \mathrm{~A}$ is the antithetic relation between smectite on the one hand and illite and chlorite on the other. Three relatively smectite-poor intervals of moderate thickness-in the bottom part, around $145 \mathrm{mbsf}$ and around $75 \mathrm{mbsf}$-are each overlain by thicker, relatively smectite-rich intervals. Our smectite-poor intervals correspond with clay mineral zones 1 and 2, clay mineral zone 5, and clay mineral zone 7 in the record of DSDP Site 132 (Chamley, 1975a, 1983). The lowest smectite-poor interval, for which $\mathrm{CaCO}_{3}$ percentages are not available, corresponds with the basal part of lithological subunit Ic (Fig. 3). The base of the highest smectite-poor interval is at the same level as the base of lithological subunit Ia, i.e., the lowest recorded sapropelic sediment and a shift toward slightly lower calcium carbonate contents. The middle smectite-poor interval, around $145 \mathrm{mbsf}$, is distinguished by relatively high carbonate contents. While smectite, illite, and chlorite display these significant changes, kaolinite abundances remain rather stable. The relatively kaolinite-poor lowermost $15 \mathrm{~m}$ of the record are an exception.

Another feature of the clay mineral distribution is the overall upward decrease of palygorskite and sepiolite from the basal part to about $75 \mathrm{mbsf}$ and their recurrence at approximately 55, 30 , and $10 \mathrm{mbsf}$, which each time is close to the top of a group of sapropels. Irregularly-mixed-layers are somewhat more abundant in the upper $60 \mathrm{~m}$ of the record and in some samples of the lowermost part. This pattern also appears in the curve of irregular-mixed-layer percentages relative to chlorite plus illite (Fig. 3). The peak-height ratio curves of Figure 3 illustrate the variations in relative abundances of the clay minerals.

Since the illite peak-breadth values are positively correlated with the palygorskite percentages $(r=0.45 ; \mathrm{p}<0.001)$, the illite crystallinity measurements appear to be influenced by the presence of palygorskite. We therefore no longer consider the significance of the illite crystallinity values, whereas in the paper on DSDP Site 132 (Chamley, 1975a) these values were taken into account.

\section{Correlations Between Clay Minerals}

In order to gain more insight into the structure of the dataset of clay mineral percentages, we calculated the correlations between the various clay minerals. Statistically significant correlations are depicted in Figure 4A (for coefficients see Table 1). 
The majority of the significant correlations, 13 of 18 , are negative. For smectite combinations not a single positive significant correlation was found. The strongest correlation is a negative one, that of smectite with illite $(r=-0.85$; Table 1). The positive correlation between chlorite and illite is the strongest but one correlation, and it is followed by the negative correlation of smectite with chlorite (Table 1). Strong positive correlations $(\mathrm{p}<0.01)$ are furthermore found between palygorskite and sepiolite and between the two types of irregular-mixedlayers.

It should be realized that (part of) the correlations between the clay minerals may be due to the effect of the closed sum $(100 \%)$. In order to eliminate possible artificial relationships created by the closed sum effect we used the computer program BALANC (Drooger, 1982). This program is based on the freeopen-covariances model of Drooger and finds a balanced solution (in our case $\Sigma R d R=0$ ) by means of an iterative process. The new matrix of significant correlation is shown in Figure 4B (see also Table 1). The BALANC procedure results in less and mainly positive significant correlations, in seven of nine cases. Among the strong negative correlations which have disappeared are those of smectite with chlorite and with illite. Only two negative significant correlations remain: the chlorite-smectite irregular-mixed-layers with chlorite $(\mathrm{p}<0.01)$ and with illite $(\mathrm{p}<$ 0.05 ). The strong positive correlations between chlorite and illite, between palygorskite and sepiolite, and between the two types of interstratified layers remain and both palygorskite and sepiolite are now firmly correlated with smectite. The results of BALANC thus suggest that artificial relationships between clay minerals are created by the closed sum. It is not possible to single out one most "disturbing" component. Smectite and illite (together with chlorite) both behave as squeezers, but from the percentage curves in Figure 4, it appears that they mainly squeeze each other.

\section{INTERPRETATION}

Below we will use the BALANC correlations (Fig. 4B) in order to determine the provenance and climatic significance of the different clay minerals. In our paleoenvironmental interpretation of the clay mineral curves we will focus our attention on the opposing, fluctuating patterns of illite and chlorite on the one hand and smectite on the other.

\section{Provenance and Climatic Significance of the Clay Minerals}

Illite and chlorite, strongly correlated according to the BALANC procedure, are produced mainly by physical weathering of metamorphic and igneous rocks (Millot, 1970; Barnhisel, 1977; Fanning and Keramidas, 1977). The two minerals are affected by hydrolyzation, chlorite being more vulnerable to chemical weathering than illite (Millot, 1970). The illite and chlorite in Hole 653A were probably derived from a proximal source. We deduce this from the spatial distribution of chlorite in the Pliocene of the central Mediterranean and the positive correlation of illite to chlorite. Hole $653 \mathrm{~A}$ is situated about $150 \mathrm{~km}$ east of Sardinia and about $165 \mathrm{~km}$ southwest of the nearest shore of the Italian mainland. A comparison between the clay mineral records for the Pliocene of Hole 653A and Pliocene sections in Sicily and Calabria demonstrates that the clay mineral associations in the Sicilian sediments are the poorest in chlorite (De Visser, in prep.). It seems that the Paleozoic crystalline basements of Sardinia and Calabria were a source of chlorite already at that time. Also nowadays high amounts of chlorite, and of illite as well, are transported from the Sardinian and $\mathrm{Ca}$ labrian crystalline rocks (Tomadin, 1981).

Kaolinite is exclusively formed by chemical weathering. Welldrained soils of upstream areas in a warm and humid climate are often rich in kaolinite (Paquet, 1970; Allen and Fanning, 1983). Once formed, kaolinite is a very stable mineral. The positive correlation, although not strong, of kaolinite with illite suggests that in Hole 653A a considerable part of the kaolinite is recycled, i.e., reworked from older soils or sediments. In the present-day Mediterranean Sea kaolinite reaches maximum relative abundances in surface sediments of regions far removed from the Mediterranean shores (Venkatarathnam and Ryan, 1971; Venkatarathnam et al., 1972; Tomadin, 1974, 1981; Chester et al., 1977; Emelyanov and Shimkus, 1986). This pattern is most probably caused by a major supply of kaolinite in the form of dust carried by sirocco winds of North African provenance (Chester et al., 1977; Prodi and Fea, 1979; Tomadin, 1981; Tomadin et al., 1984). Also in our record a portion of the kaolinite might have such an eolian origin, but a proximal source cannot be excluded.

The continental formation of smectite, palygorskite, and sepiolite, between which strong positive correlations were found (Fig. 4B), requires the accumulation of basic cations. Smectite originates mainly in poorly drained soils of downstream areas under semiarid conditions, but also in soils in the early stages of weathering under a temperate climate. Another source of smectite is the subareal and submarine alteration of volcanic ash and tuff (Pédro, 1968; Millot, 1970; Paquet, 1970; Allen and Fanning, 1983). In the interpretation of the clay mineral record for the earlier DSDP Site 132, the abundance of smectite has been positively related to the degree of humidity (Chamley, 1975a).

Palygorskite and sepiolite are formed mainly in marginalmarine and lacustrine, chemically restricted environments in arid and semiarid regions (Millot, 1970; Wiersma, 1970; Isphording, 1973; Weaver and Beck, 1977; Chamley et al., 1981; Singer and Galan, 1984). Previous research on the marine Pliocene and Quaternary of the Mediterranean has shown that palygorskite is best considered to be reworked from Paleogene North African sediments (Chamley and Millot, 1975; Chamley, 1975a and b, 1976; Chamley et al., 1977).

The strong positive correlation of smectite with palygorskite and sepiolite (Fig. 4B) is difficult to explain. If we accept a North African source for palygorskite, and for the positively correlated sepiolite too, we may envisage a larger supply of these two minerals during more humid periods in which more smectite-rich soils were formed and eroded. An alternative explanation for the correlation of smectite with palygorskite and sepiolite is that smectite too is largely reworked. This seems less probable.

A model for a larger supply of palygorskite and sepiolite during more humid periods has to include the transport path of the minerals from a North African source to the Tyrrhenian Sea. Saharan winds are reported to carry noticeable amounts of palygorskite to the Mediterranean (Tomadin et al., 1984; Robert et al., 1984; Coudé-Gaussen and Blanc, 1985). Also during the Pliocene and Quaternary, palygorskite may have been transported from the source area to the north as eolian dust. The further path of the wind-transported palygorskite (and sepiolite) can be and might have been complicated. We may imagine, for instance, subsequent settling from orographic rains on the Tyrrhenian drainage areas followed by fluvial and marine transport from these areas to the ultimate site of deposition. The two main phases of transport, by air and by wind, may have taken place under different climatic conditions. We therefore cannot draw the straightforward conclusion that there is a correlation between more humid climatic conditions (formation of smectite) and stronger, or a more frequent occurrence of, dust-loaded Saharan winds (supply of palygorskite and sepiolite).

Illite-smectite and chlorite-smectite irregular-mixed-layers, positively correlated according to BALANC (Fig. 4B), are generally formed by moderate weathering, which occurs under less arid, 


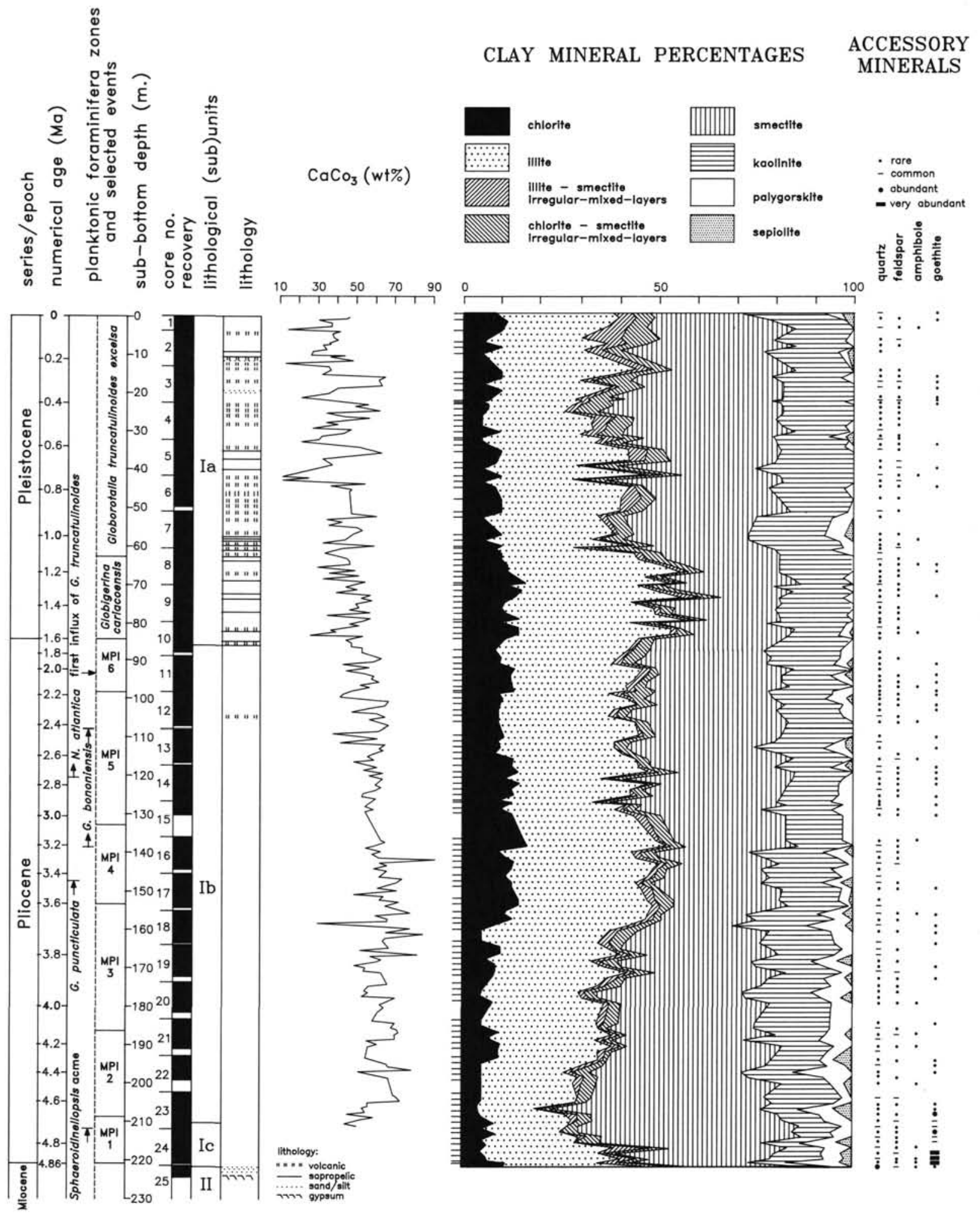

Figure 3. Clay mineral percentages, semiquantitative abundances of accessory minerals, and clay mineral relative abundances at Hole 653A. Planktonic foraminifer zones, lithological (sub)units, and carbonate percentages are from Kastens, Mascle, et al. (1987) (site reports). Selected planktonic foraminifer events are from this Volume and from Glaçon (pers. comm.). Lithological unit 1: foraminiferal nannofossil ooze with a low mud content (subunit la: less calcareous; subunit lb: more calcareous; subunit lc: reddish and yellowish). Lithological unit 2: restricted marine to continental sediments. Carbonate percentages from sapropels and volcanic ash layers are not given. Those parts of the peak-height ratio curves and of the irregular-mixed-layers/(chlorite + illite) percentage ratio curve which overstep their means are shaded. 
CLAY MINERAL RELATIVE ABUNDANCES

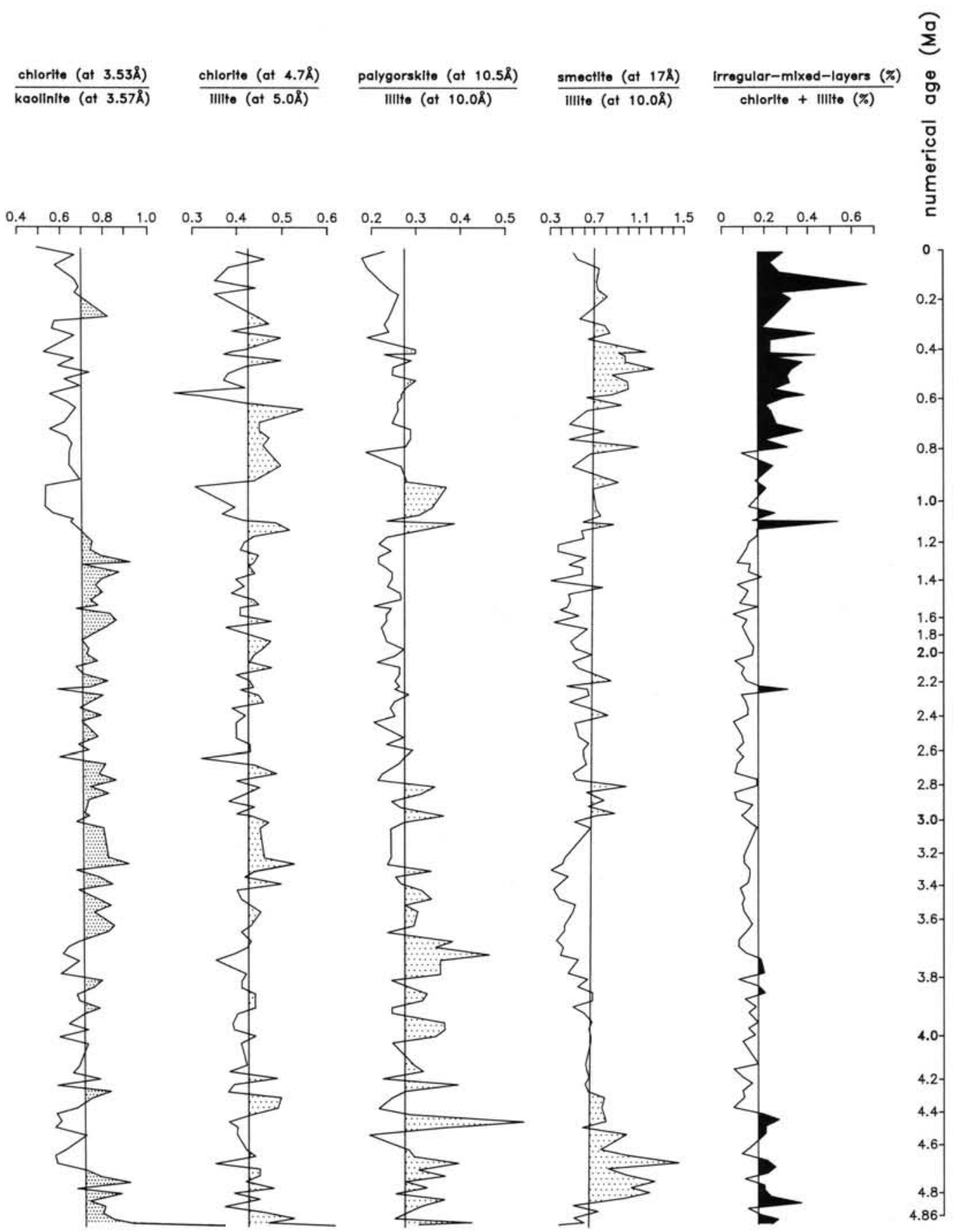

Figure 3 (continued).

often cooler climatic conditions and in areas with a steep relief (Millot, 1970; Chamley, 1971).

Summarizing, three clay minerals in our record are suspected of not (or hardly) being formed in contemporaneous soils. These are kaolinite, palygorskite, and sepiolite. It is not clear if, to what extent, and exactly how the abundances of these minerals are related to wind-patterns. Of the other minerals, chlorite and illite can be related to the intensity of mechanical weathering, thus to the degree of aridity and to relief (relative sea level). Smectite can be related to the degree of humidity and to volcanism. The irregular-mixed-layers can be related to moderate chemical weathering, which is characteristic for a relatively cool climate.

\section{Paleoenvironmental Interpretation}

If we relate a larger amount of smectite in our record to a more humid continental climate, as in the earlier paper on 
A

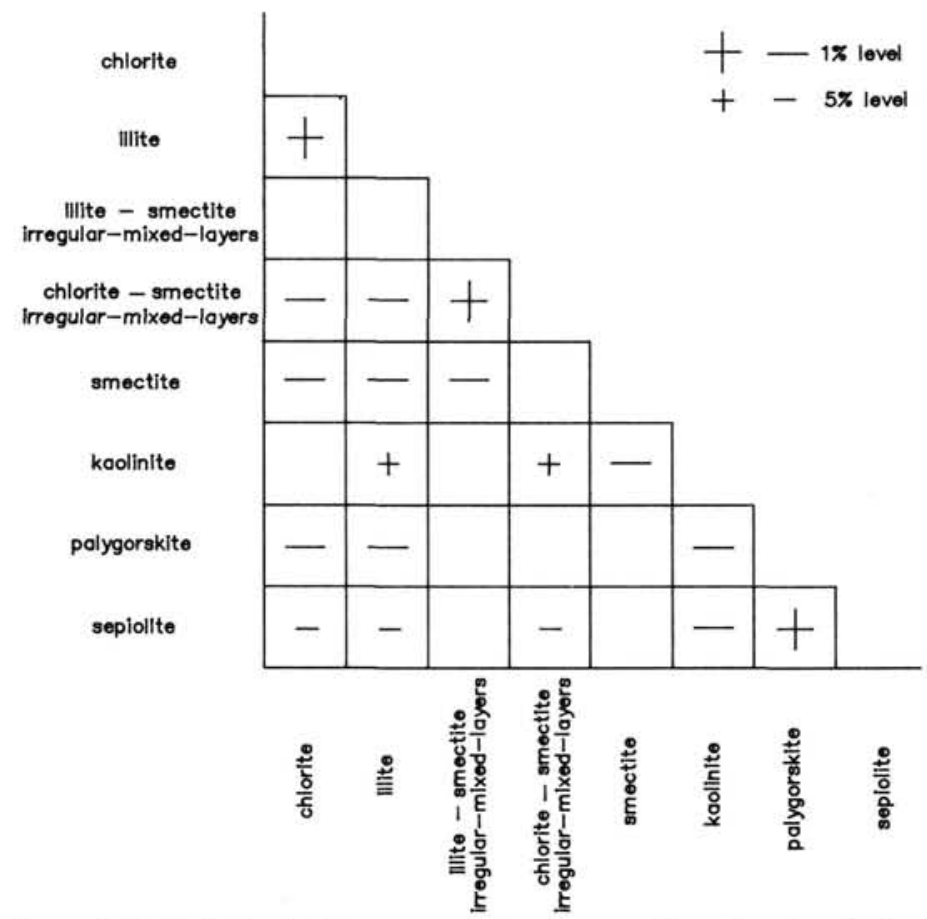

B

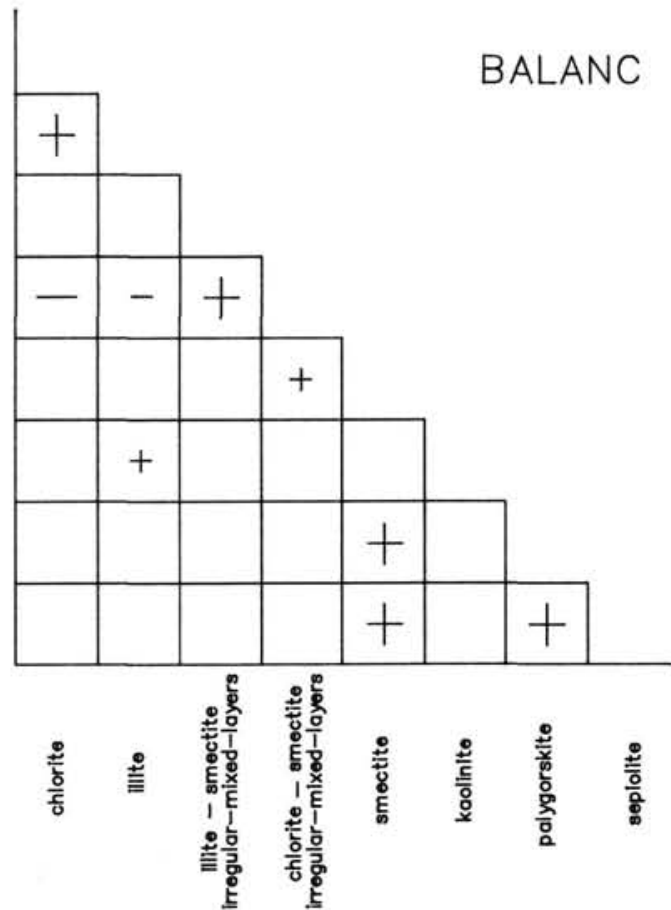

Figure 4. Statistically significant correlations between clay minerals at Hole 653A. A. Before the BALANC procedure. B. After the BALANC procedure.

Table 1. Coefficients of correlation between clay minerals, before and after the BALANC procedure.

\begin{tabular}{|c|c|c|c|c|c|c|c|c|}
\hline \multicolumn{9}{|c|}{ Before BALANC } \\
\hline chlorite & 1 & 0.64 & -0.16 & -0.37 & -0.56 & -0.14 & -0.36 & -0.20 \\
\hline illite & 2 & & 0.01 & -0.33 & -0.85 & 0.17 & -0.32 & -0.21 \\
\hline illite-smectite & 3 & & & 0.39 & -0.24 & -0.03 & -0.03 & -0.04 \\
\hline chlorite-smectite & 4 & & & & 0.06 & 0.23 & -0.14 & -0.17 \\
\hline smectite & 5 & & & & & -0.38 & 0.11 & 0.10 \\
\hline kaolinite & 6 & & & & & & -0.27 & -0.26 \\
\hline palygorskite & 7 & & & & & & & 0.41 \\
\hline \multirow[t]{2}{*}{ sepiolite } & 8 & & & & & & & \\
\hline & & 2 & 3 & 4 & 5 & 6 & 7 & 8 \\
\hline \multicolumn{9}{|c|}{ After BALANC } \\
\hline chlorite & 1 & 0.73 & -0.08 & -0.26 & -0.03 & -0.06 & -0.15 & -0.06 \\
\hline illite & 2 & & 0.09 & -0.18 & 0.01 & 0.20 & 0.02 & 0.03 \\
\hline illite-smectite & 3 & & & 0.41 & -0.04 & -0.08 & 0.04 & 0.01 \\
\hline chlorite-smectite & 4 & & & & 0.21 & 0.15 & -0.02 & -0.08 \\
\hline smectite & 5 & & & & & -0.03 & 0.31 & 0.23 \\
\hline kaolinite & 6 & & & & & & -0.07 & -0.11 \\
\hline palygorskite & 7 & & & & & & & 0.44 \\
\hline \multirow[t]{2}{*}{ sepiolite } & 8 & & & & & & & \\
\hline & & 2 & 3 & 4 & 5 & 6 & 7 & 8 \\
\hline
\end{tabular}

DSDP Site 132 (Chamley, 1975a), then the low relative abundances of this mineral (Fig. 3) would indicate relatively dry periods during the earliest Pliocene, the middle Pliocene, and the early Pleistocene. A sharp increase of humidity then characterizes the earliest Pliocene, a gradual decrease of humidity characterizes the early Pliocene, and a stable relatively humid climate the late Pliocene. There are, however, some serious flaws in this explanation. During the earliest Pliocene, a rather unique assemblage accompanies the low smectite abundance, namely high abundances of illite, and in particular exceptionally high abundances of the iron-oxyhydroxide goethite. Such an assemblage could very well be explained by massive reworking as an after- math of the Messinian salinity crisis (compare Chamley, 1975a, 1983).

The interference of the combined illite and chlorite pattern with the smectite pattern is yet another problem. Since illite and chlorite are dependent on the degree of physical weathering, the patterns of these minerals suggest a strong increase in erosion from 4.6 to $3.4 \mathrm{Ma}$. Another period characterized by increased erosion begins at $1.6 \mathrm{Ma}$. It is not clear whether the changes in the erosional patterns were caused by relative sea-level changes, tectonic movements, or aridity changes. It is obvious, however, that the middle Pliocene and early Pleistocene periods with low smectite abundance, interpreted as dry, could equally well be in- 
terpreted as periods of increased physical weathering by uplift or by eustatic sea-level lowering. In particular the late Plioceneearly Pleistocene shift toward lower calcium carbonate values (Fig. 3) indicates a larger flux of chlorite-rich and illite-rich terrigenous material due to an accelerated tectonic uplift and emergence of the peri-Tyrrhenian areas or to a eustatic sea-level lowering. Large-scale tectonic emergence of peri-Tyrrhenian regions is known to have taken place during the latest Pliocene and Quaternary (see for instance Baggioni-Lippmann, 1982; Bartolini et al., 1982; Hugonie, 1982; Ciaranfi et al., 1983). According to Haq et al. (1987), drops in eustatic sea-level occurred at $3.8,2.9,1.6$, and $0.8 \mathrm{Ma}$. In our record, four mutually comparable changes in clay mineral distribution do not emerge from the levels corresponding to these ages in our record. We are therefore inclined to attribute the illite plus chlorite signal to tectonic uplift rather than to sea-level lowering.

The next major change in the clay mineral distribution is an increase of irregular-mixed-layers and smectite in the lower Pleistocene (Fig. 3). The slightly larger abundance of irregular-mixedlayers in the upper part of the Pleistocene sequence, nicely exemplified by the curve of irregular-mixed-layers relative to chlorite plus illite percentages (Fig. 3), points to a cooler climate. This larger proportion of irregular-mixed-layers is unlikely to have originated from a steepening of relief, because the mixed layers increase at the expense of chlorite and illite, which are products of physical weathering. The larger abundance of smectite in the same interval might indicate that the climate had become not only cooler, but more humid as well. However, it does not seem to be mere coincidence that in the relatively smectiterich Pleistocene sequence a large number of volcaniclastic layers are intercalated. Along the Italian peninsula extensive volcaniclastic series formed during the Quaternary in Latium, Campania, and the Eolian arc (Marinelli, 1975; Beccaluva et al., 1985; Locardi, 1985; Larouzière, 1987). More specifically, the widespread potassium-rich volcanism of the Tyrrhenian side of the Apennines is reported to be less than about 1.0 Ma old (Marinelli, 1975; Locardi, 1985). The weathering of volcanic rocks often results in the formation of smectite-rich soils; so the abundance of smectite during the last $1.0 \mathrm{Ma}$ may equally well have originated from the Italian volcanic areas. Since our clay mineral record includes no samples from volcanic ash layers, in which smectite can be formed during diagenesis, the abundance of smectite does not seem to be caused by submarine alteration of volcanic material.

\section{COMPARISON WITH POLLEN AND FORAMINIFERAL RECORDS}

On the basis of pollen analysis performed on northwest Mediterranean marine sequences, Suc $(1984,1986)$ inferred a change in the planktonic foraminifer zone MP14 from a moist climate with rainy summers to a climate with larger seasonal contrast and drier summers. Around $2.4 \mathrm{Ma}$ the climate starts to fluctuate between relatively dry and relatively humid. In the southern Italian Vrica section, Combourieu-Nebout (1987) recognized two periods of deteriorated climate, from 2.1 to $2.0 \mathrm{Ma}$ and from 1.7 to $1.5 \mathrm{Ma}$. The amplitude of the climatic oscillations increases during the Quaternary and gradually a strong correlation between dry and cool and between humid and warm is established (Suc, 1984). These alternating climatic conditions are considered to coincide with glacial and interglacial cycles in northern Europe (Suc and Zagwijn, 1983; Zagwijn and Suc, 1984; Combourieu-Nebout, 1987).

It seems that it is only the aridification during MP14 (Suc, 1984,1986 ) which can be recognized in our clay mineral curves. The major cooling event in the middle of MPI 5, recognized in the pollen records (Suc., 1984, 1985) as well as in stable isotope (Thunell and Williams, 1983), planktonic foraminifers (Zacha- riasse and Spaak, 1983) and calcareous nannofossil (Driever, 1984) records, is not seen in the clay minerals. The early Pleistocene onset of a cooler climate, suggested by the pattern of irregular-mixed-layers, is supported by isotope data (Thunell and Williams, 1983) and faunal data (Cita et al., 1973; Thunell, 1979).

\section{CONCLUSIONS}

We are inclined to believe that in Hole $653 \mathrm{~A}$ we are dealing with a clay mineral record that reflects tectonic uplift trends as well as climatic changes. Superimposed we can distinguish reworking within the lowermost Pliocene and we cannot exclude a signal of increased volcanism in the source areas during the Pleistocene. A portion of kaolinite, palygorskite, and sepiolite was probably not formed in contemporaneous soils. These minerals are suspected of being wind-supplied from North African sources.

The higher abundance of illite plus chlorite in the lowermost Pleistocene is probably due to tectonic uplift of peri-Tyrrhenian regions. Higher abundances of irregular-mixed-layers must be attributed to a strong cooling trend starting in the early Pleistocene. At the moment we are doubtful whether the low smectite abundance during MP14 does indeed indicate aridity. Data concerning the timing and magnitude of tectonic uplift in the periTyrrhenian area are needed to establish the significance of this clay mineral signal.

\section{ACKNOWLEDGMENTS}

The authors are grateful to G. J. van der Zwaan, K. Kastens, C. W. Drooger, J-F. Deconinck, J. E. Meulenkamp, J. Mascle, and F. W. McCoy for reviewing the manuscript. J. W. Zachariasse reviewed the part on biochronology; his contribution is highly appreciated. The X-ray analyses were skillfully performed by P. Recourt. S. M. McNab made linguistic corrections. The first author is grateful for the financial support given by the Netherlands Organization of Scientific Research. The second author acknowledges grant ATP-990 from the Centre National de la Recherche Scientifique, France.

\section{REFERENCES}

Aguirre, E., and Pasini, G., 1985. The Pliocene-Pleistocene Boundary. Episodes, 8:116-120.

Allen, B. L., and Fanning, D. S., 1983. Composition and soil genesis. In Wilding, L. P., Smeck, N. E., and Hall, G. F. (Eds.), Pedogenesis and soil taxonomy, I. Concepts and Interactions. Developments in Soil Science (Vol 11A): Amsterdam (Elsevier), 141-192.

Baggioni-Lippmann, M., 1982. Néotectonique et géomorphologie dans l'Apennin campanien (Italie méridionale). Rev. Géol. Dyn. Géogr. Phys., 23:41-54.

Barnhisel, R. I., 1977. Chlorites and hydroxy interlayered vermiculite and smectite. In Dixon, J. B., and Weed, S. B. (Eds.), Minerals in Soil Environments. Soil. Sci. Soc. Am. (Madison, WI), 331-356.

Bartolini, C., Bernini, M., et al., 1982. Carta neotettonica dell'Appennino settentrionale. Note illustrative. Boll. Soc. Geol. It., 101:523549.

Beccaluva, L., Gabianelli, G., Lucchini, F., Rossi, P. L., and Savelli, C., 1985. Petrology and K/Ar ages of volcanics dredged from the Eolian seamounts: implications for geodynamic evolution of the southern Tyrrhenian basin. Earth Planet. Sci. Lett., 74:187-208.

Berggren, E., Kent, D. V., and Van Couvering, J. A., 1985. The Neogene: Part 2. Neogene geochronology and chronostratigraphy. In Snelling, N. J. (Ed.), The Chronology of the Geological Record. Geol. Soc. London, Mem., 10:211-260.

Chamley, H., 1971. Recherches sur la sédimentation argileuse en Méditerranée. Sci. Géol., Strasbourg, Mém., 35:1-225.

1975a. Sédimentation argileuse en mer Tyrrhénienne au PlioPléistocène d'après l'étude du forage Joides 132. Bull. Groupe Fr. Argiles, 27:97-137.

1975b. Sédimentation argileuse en mer Ionienne au PlioPléistocène d'après 1'étude des forages 125 DSDP. Bull. Soc. Géol Fr., 7:1131-1143. 
1976. Minéralogy des argiles, lithologie et tectonique, dans le Pliocène du Capo Rossello (Sicile). C.R. Somm. Soc. Géol. Fr., 2: 39-41.

1983. Marine and continental antagonistic influences in Mediterranean Late Neogene to Recent clay sedimentation. In Meulenkamp, J. E. (Ed.), Reconstruction of marine paleoenvironments. Utrecht Micropaleontol. Bull., 30:71-90.

Chamley, H., and Millot, G., 1975. Observations sur la répartition et la genèse des attapulgites plio-quaternaires de Méditerranée. C.R. Acad. Sci., Paris, D, 281:1215-1218.

Chamley, H., Colomb, E., and Roux, M. R., 1981. Dépots lacustres a argiles fibreuses dans le Miocène supérieur de la Basse-Durance (Sud-Est de la France). Ann. Soc. Géol. Nord, 100:43-56.

Chamley, H., Giroud d'Argoud, G., and Robert, C., 1977. Repercussions of the Plio-Pleistocene tectonic activity on the deep-sea clay sedimentation in the Mediterranean. In Biju-Duval, B., and Montadert, L. (Eds.), International Symposium on Structural History of Mediterranean Basins., Paris (Split. Technip.), 423-432.

Chester, R., Baxter, G. G., Behairy, A.K.A., Connor, K., Cross, D., Elderfield, H., and Padgham, R. C., 1977. Soil-sized eolian dusts from the lower troposphere of the eastern Mediterranean. Mar. Geol., 24:201-217.

Ciaranfi, N., Guida, M., et al., 1983. Elementi sismotettonico dell'Appennino meridionale. Boll. Soc. Geol. It., 102:201-222.

Cita, M. B., 1973. Pliocene biostratigraphy and chronostratigraphy. In Ryan, W.B.F., Hsü, K. J., et al., Init. Repts. DSDP, 13: Washington (U.S. Govt. Printing Office), 1343-1379.

1975. Planktonic foraminiferal biozonation of the Mediterranean Pliocene deep sea record. A revision. Riv. It. Paleontol., 81: 527-544.

Cita, M. B., Chierici, M. A., Ciampo, G., Moncharmont Zei, M., D'Onofrio, S., Ryan, W.B.F., and Scorziello, R., 1973. The Quaternary record in the Tyrrhenian and Ionian Basins of the Mediterranean Sea. In Ryan, W.B.F., Hsü, K. J., et al., Init. Repts. DSDP, 13: Washington (U.S. Govt. Printing Office), 1263-1339.

Combourieu-Nebout, N., 1987. Les premiers cycles glaciaire-interglaciaire en région méditerranéenne d'après l'analyse palynologique de la série Plio-P1éistocène de Crotone (Italie). [Ph.D. dissert.] Montpellier Univ., France.

Coudé-Gaussen, G., and Blanc, P., 1985. Présence de grains éolisés de palygorskite dans les poussières actuelles et les sédiments récents d'origine désertique. Bull. Soc. Géol. Fr., 1:571-579.

Driever, B.W.M., 1984. The terminal record of Discoaster in the Mediterranean and in the Atlantic DSDP site 397, and the Pliocene-Pleistocene boundary. Kon. Ned. Akad. Wetensch., Proc. Ser. B, 87:77102.

Drooger, M. M., 1982. Quantitative range chart analyses. Utrecht Micropaleontol. Bull., 26:1-227.

Emelyanov, E. M., and Shimkus, K.M., 1986. Geochemistry and Sedimentology of the Mediterranean Sea. Dordrecht (Riedel), 1-553.

Fanning, D. S., and Keramidas, V. Z., 1977. Micas. In Dixon, J. B., and Weed, S. B. (Eds.), Minerals in Soil Environments. Soil Sci. Soc. Am. (Madison, WI), 195-255.

Haq, B. U., Hardenbol, J., and Vail, P. R., 1987. Chronology of fluctuating sea levels since the Triassic. Science, 235:1156-1167.

Hilgen, F. J., 1987. Sedimentary rhythms and high-resolution chronostratigraphic correlations in the Mediterranean Pliocene. Newsl. Stratigr., 17: 109-127.

Hilgen, F. J., and Langereis, C. G., in press. The age of the MiocenePliocene boundary in the Capo Rossello area (Sicily). Earth Planet. Sci. Lett.

Holtzapffel, T., 1985. Les minéraux argileux. Préparation, analyse diffractométrique et détermination. Villeneuve d'Ascq, France (Publ. Soc. Géol. Nord), 12:136.

Hugonie, G., 1982. Mouvements tectoniques et variations de la morphogenèse au Quaternaire en Sicile Septentrionale. Rev. Géol. Dyn. Géogr. Phys., 23:3-14.

Isphording, W. C., 1973. Discussion of the occurrence and origin of sedimentary palygorskite-sepiolite deposits. Clays and Clay Minerals, 21:391-401.

Kastens, K. A., Mascle, J., et al., 1987. Proc. ODP, Init. Repts., 107: College Station, TX (Ocean Drilling Program).
Kübler, B., 1966. La cristallinité de l'illite et les zones tout a fait supérieures du métamorphisme. Etages tectoniques. Neuchatel (A. la Baconnière), 105-122.

Larouzière, F.-D., 1987. Environnement volcanique plio-pléistocène du Détroit de Messine (Italie). In Barrier, P., Di Geronimo, I., and Montenat, C. (Eds.) Le Détroit de Messine (Italie). Evolution tectono-sédimentaire récente (Pliocène et Quaternaire) et environnement actuel. Doc. Trav. IGAL, Paris, 11:29-34.

Locardi, E., 1985. Neogene and Quaternary Mediterranean Volcanism: The Tyrrhenian Example. In Stanley, D. J., and Wezel, F.-C. Geological Evolution of the Mediterranean Basins. New York (Springer), 273-291.

Marinelli, G., 1975. Magma evolution in Italy. In Squyres, C. H. (Ed.) Geology of Italy. Tripoly (Earth Sci. Soc. Libyan Arab Republic), 165-219.

Millot, G., 1970. Geology of Clays; Weathering, Sedimentology, Geochemistry. Paris (Masson), 1-429.

Paquet, H., 1970. Evolution géodynamique des minéraux argileux dans les altérations et les sols des pays méditerranéens à saisons contrastées. Mém. Serv. Carte Géol. Als. Lorr., 30:210.

Pédro, G., 1968. Distribution des principaux types d'alteration chimique à la surface du globe. Présentation d'une esquisse géographique. Rev. Géogr. Phys. Géol. Dyn., 10:457-470.

Prodi, F., and Fea, G., 1979. A case of transport and deposition of Saharan dust over the Italian Peninsula and Southern Europe. J. Geophys. Res., 84:6951-6960.

Rio, D., and Sprovieri, R., 1986. Biostratigrafia integrata del PliocenePleistocene inferiore mediterraneo in un'ottica di Stratigrafia Sistematica. Boll. Soc. Paleontol. It., 25:65-85.

Rio, D., Sprovieri, R., and Raffi, I., 1984. Calcareous plankton biostratigraphy and biochronology of the Pliocene-Lower Pleistocene succession of the Capo Rossello area, Sicily. Mar. Micropaleontol., 19:135-180.

Robert, C., Gauthier, A., and Chamley, H., 1984. Origine autochtone et allochtone des argilles récentes de haute altitude en Corse. Géol. Méditerranéenne, 11:243-253.

Ruggieri, G., and Sprovieri, R., 1983. Recenti progressi nella stratigrafia del Pleistocene inferiore. Boll. Soc. Paleontol. It., 22:315-321.

Ruggieri, G., Rio, D., and Sprovieri, R., 1984. Remarks on the chronostratigraphic classification of Lower Pleistocene. Boll. Soc. Geol. It., 103:251-259.

Ryan, W.B.F., Hsü, K. J., et al., 1973. Tyrrhenian Rise-Site 132. In Ryan, W.B.F., Hsü, K. J., et al., Init. Repts. DSDP, 13: Washington (U.S. Govt. Printing Office), 403-464.

Shipboard Scientific Party, 1987. Site 653. In Kastens, K. A., Mascle, J., et al., Proc. ODP, Init. Repts., 107: College Station, TX (Ocean Drilling Program).

Singer, A., and Galan, E. (Eds.), 1984. Palygorskite-Sepiolite. Occurrences, Genesis and Uses. Developments in sedimentology, Amsterdam (Elsevier), 1-352.

Suc, J.-P., 1984. Origin and evolution of the Mediterranean vegetation and climate in Europe. Nature, 307:429-432.

, 1986. Flores néogène de Méditerranée occidentale. Climat et Paléogéographie. Bull. Centres Rech. Explor.-Prod. Elf-Aquitaine, 10:477-488.

Suc, J.-P., and Zagwijn, W. H., 1983. Plio-Pleistocene correlations between the northwestern Mediterranean region and northwestern Europe according to recent biostratigraphic and palaeoclimatic data. Boreas, 12:153-166.

Tauxe, L., Opdyke, N. D., Pasini, G., and Elmi, C., 1983. Age of the Plio-Pleistocene boundary in the Vrica section, southern Italy. $\mathrm{Na}$ ture, 304:125-129.

Thunell, R. C., 1979. Pliocene-Pleistocene paleotemperature and paleosalinity history of the Mediterranean Sea: results from DSDP Sites 125 and 132. Mar. Micropaleontol., 4:173-187.

Thunell, R. C., and Williams, D. F., 1983. The stepwise development of Pliocene-Pleistocene paleoclimatic and paleoceanographic conditions in the Mediterranean: oxygen isotopic studies of DSDP sites 125 and 132. In Meulenkamp, J. E. (Ed.) Reconstruction of marine paleoenvironments. Utrecht Micropaleontol. Bull., 30:111-127.

Tomadin, L., 1974. Les minéraux argileux dans les sediments actuels de la Mer Tyrrhénienne. Bull. Groupe Fr. Argiles, 26:219-228. 
1981. Provenance and dispersal of clay minerals in recent sediments of the Central Mediterranean Sea. In Wezel, F. C. (Ed.), Sedimentary basins of Mediterranean margins. C.N.R. Italian Project of Oceanography, Bologna (Tecnoprint), 313-324.

Tomadin, L., Lenaz, R., Landuzzi, V., Mazzucotelli, A., and Vannucci, R., 1984. Wind-blown dust over the Central Mediterranean. Oceanologica Acta, 7:13-23.

Venkatarathnam, K., and Ryan, W.B.F., 1971. Dispersal patterns of clay minerals in the sediments of the eastern Mediterranean Sea. Mar. Geol., 11:261-469.

Venkatarathnam, K., Biscaye, E., and Ryan, W.B.F., 1972. Origin and Dispersal of Holocene Sediments in the Eastern Mediterranean Sea. In Stanley, D. J. (Ed.) The Mediterranean Sea; a natural sedimentation laboratory. Stroudsburg, PA (Hutchinson and Ross), 455-469.

Weaver, C. E., and Beck, K. C., 1977. Miocene of the S.E. United States: a model for chemical sedimentation in a peri-marine environment. Sediment. Geol., 17:1-234.

Wiersma, J., 1970. Provenance, genesis and paleogeographical implications of microminerals occurring in sedimentary rocks of the Jordan Valley area. Publ. Fys. Geogr. Bodemkd. Lab. Univ. Amsterdam, 15:1-240.

Zachariasse, W. J., and Spaak, P., 1983. Middle Miocene to Pliocene paleoenvironmental reconstruction of the Mediterranean and adjacent Atlantic Ocean: planktonic foraminiferal record of southern Italy. In Meulenkamp, J. E. (Ed.) Reconstruction of marine paleoenvironments. Utrecht Micropaleontol. Bull., 30:91-110.

Zagwijn, W. H., and Suc, J-P., 1984. Palynostratigraphie du Plio-Pléistocène d'Europe et de Méditerranee nord occidentale: correlations chrono-stratigraphiques, histoire de la végétation et du climat. $\mathrm{Pa}$ léobiol. Cont., 14:475-483.

Zijderveld, J.D.A., Zachariasse, J. W., Verhallen, P.J.J.M., and Hilgen, F. J., 1986. The age of the Miocene-Pliocene boundary. Newsl. Stratigr., 16:169-181.

Date of initial receipt: December 1987

Date of acceptance: 10 January 1989

Ms 107B-123

\section{APPENDIX: \\ Biochronology of Hole 653A}

The sediment accumulation curves for Holes $652 \mathrm{~A}$ and $654 \mathrm{~A}$ (see Fig. 5) are based on the stratigraphic position and age of identified paleomagnetic polarity zones (Shipboard Scientific Party, 1987) and are used to interpolate the age of the Miocene/Pliocene boundary and planktonic foraminifer datums. These age-calibrated events are used to reconstruct the chronology of Hole 653A (Fig. 3).

Globigerina cariacoensis/Globorotalia truncatulinoides excelsa zonal boundary. This boundary corresponds with the first occurrence of Globorotalia truncatulinoides excelsa (Ruggieri and Sprovieri, 1983). The low recovery in the upper part of Hole 652A makes it highly uncertain at what stratigraphic level this taxon really enters. There are similar uncertainties concerning Holes 650A and 651A (Kastens, Mascle, et al. 1987). The base of the small-Gephyrocapsa acme in the nannofossil distribution seems to coincide approximately with the first occurrence of G.truncatulinoides excelsa (Ruggieri et al., 1984; Rio and Sprovieri, 1986) and might, therefore, help us to correlate the Globigerina cariacoensis/Globorotalia truncatulinoides excelsa zonal boundary in Holes $650 \mathrm{~A}$ and $651 \mathrm{~A}$ with this boundary in Hole $653 \mathrm{~A}$. In Holes $650 \mathrm{~A}$ and $651 \mathrm{~A}$ the influx of small-Gephyrocapsa lies below the Jaramillo subchron, which provides a minimum age of $0.98 \mathrm{Ma}$ for this bio-event. Rio, Backman, and Raffi (in Rio and Sprovieri, 1986) arrive at an age of 1.10-1.15 Ma for this event in the Mediterranean. We consider 1.10
Ma to be a fair guess for the Globigerina cariacoensis/Globorotalia truncatulinoides excelsa zonal boundary in Hole 653A.

MP16/Globigerina cariacoensis zonal boundary. A useful criterion for approximating the base of the Globigerina cariacoensis Zone is the first common occurrence of sinistrally coiled Neogloboquadrina pachyderma (see "Explanatory Notes" chapter in Kastens, Mascle, et al., 1987). This event occurs so close to the Pliocene/Pleistocene boundary in the stratotype section of Vrica (Aguirre and Pasini, 1985) that the Leg 107 shipboard party places this chronohorizon at the level of the first common occurrence of sinistral N. pachyderma. In Hole 652A this bioevent has an interpolated age of $1.55 \mathrm{Ma}$. Age estimates of 1.66 and 1.79 Ma are obtained for Holes 650A and 651A, respectively (not in Fig. $5)$. In the Pliocene/Pleistocene boundary stratotype section, common sinistral $N$. pachyderma first occurs a few meters above the top of the Olduvai subchron (Aguirre and Pasini, 1985). By extrapolating the sedimentation rate of the Olduvai subchron, on the basis of the polarity record of Tauxe et al. (1983), we arrive at an age of approximately 1.60 $\mathrm{Ma}$ for this event. This age has been used for the MP16/Globigerina cariacoensis zonal boundary in Hole 653A.

First influx of Globorotalia truncatulinoides. The first presence interval of $G$. truncatulinoides has an interpolated age of 1.96-2.14 Ma in Hole $652 \mathrm{~A}$. This influx is centered at $2.05 \mathrm{Ma}$, an age which is in good agreement with an estimate of $2.08 \mathrm{Ma}$ for the first occurrence of $G$. truncatulinoides in Sicily (Rio et al., 1984). In our chronology of Hole $653 \mathrm{~A}$ we fix the stratigraphic middle of the first presence interval of $G$. truncatulinoides at $2.05 \mathrm{Ma}$.

MP14/MP15 zonal boundary. The last occurrence of Sphaeroidinellopsis seminulina marks the boundary between MP14 and MP15 (Cita, $1973,1975)$. Interpolated ages for this event in Hole 652A and 654A are 3.07 and 2.98-3.05 Ma, respectively. These ages compare well with the age estimate of $3.05 \mathrm{Ma}$ for the exit of $S$. seminulina in Sicily (Rio et al., 1984). An age of $3.06 \mathrm{Ma}$ is used here for the MPI4/MPI5 boundary in Hole 653A.

MP13/MP14 zonal boundary. This boundary corresponds with the exit of Globorotalia margaritae (Cita 1973, 1975) and has an interpolated age of $3.40-3.60 \mathrm{Ma}$ in Hole $652 \mathrm{~A}$ and of 3.52-3.77 Ma in Hole $654 \mathrm{~A}$. These ages show a large spread, because the stratigraphic position of the base of the Gauss chron in Holes 652A and 654A and that of the top of the Cochiti subchron in Hole 654A are uncertain. Earlier age estimates for the exit of $G$. margaritae in Sicily are $3.67 \mathrm{Ma}$ (Rio et al., 1984 ) and 3.65 Ma (Hilgen, 1987). For the MPl3/MPI4 boundary in Hole $653 \mathrm{~A}$ we chose an age of $3.60 \mathrm{Ma}$.

MP12/MP13 zonal boundary. The MPI2/MPI3 boundary is defined by the entry of Globorotalia puncticulata (Cita, 1975) and has an interpolated age of $4.10 \mathrm{Ma}$ in Hole $652 \mathrm{~A}$ and of $4.28-4.35 \mathrm{Ma}$ in Hole $654 \mathrm{~A}$. An age of $4.10 \mathrm{Ma}$ is in good agreement with an age of $4.13 \mathrm{Ma}$ for this event in Calabria (Zijderveld et al., 1986) and for this reason we use an age of $4.10 \mathrm{Ma}$ for the MPI2/MPI3 zonal boundary in Hole $653 \mathrm{~A}$.

MPII/MPI2 zonal boundary. The Leg 107 party used the first occurrence of Globorotalia margaritae (Rio et al., 1984) and not the top of the Sphaeroidinellopsis acme (Cita, 1973, 1975) to mark the MPIl/MPI2 zonal boundary. In all holes this zonal boundary lies above the acme of Sphaeroidinellopsis and it has an interpolated age of $4.70 \mathrm{Ma}$ in Hole $652 \mathrm{~A}$ and of $4.72-4.74 \mathrm{Ma}$ in Hole $654 \mathrm{~A}$. For the MPll/MPI2 boundary in Hole $653 \mathrm{~A}$ we used an age of $4.71 \mathrm{Ma}$.

Miocene/Pliocene boundary. Downward extrapolation of the sedimentation rates in the Thvera subchron yields an age of $4.86 \mathrm{Ma}$ for the $\mathrm{M} / \mathrm{P}$ boundary in Hole $652 \mathrm{~A}$ and of $4.78-4.85 \mathrm{Ma}$ for the boundary in Hole 654A. An age of 4.85 or $4.86 \mathrm{Ma}$ is in good agreement with ages of 4.84 Ma for the M/P boundary in Calabria (Zijderveld et al., 1986) and of $4.86 \mathrm{Ma}$ for the boundary in Sicily (Hilgen and Langereis, in press). For Hole $653 \mathrm{~A}$ we fix the base of the Pliocene at $4.86 \mathrm{Ma}$. 


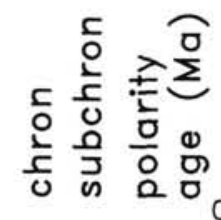
sub-bottom depth (m.)
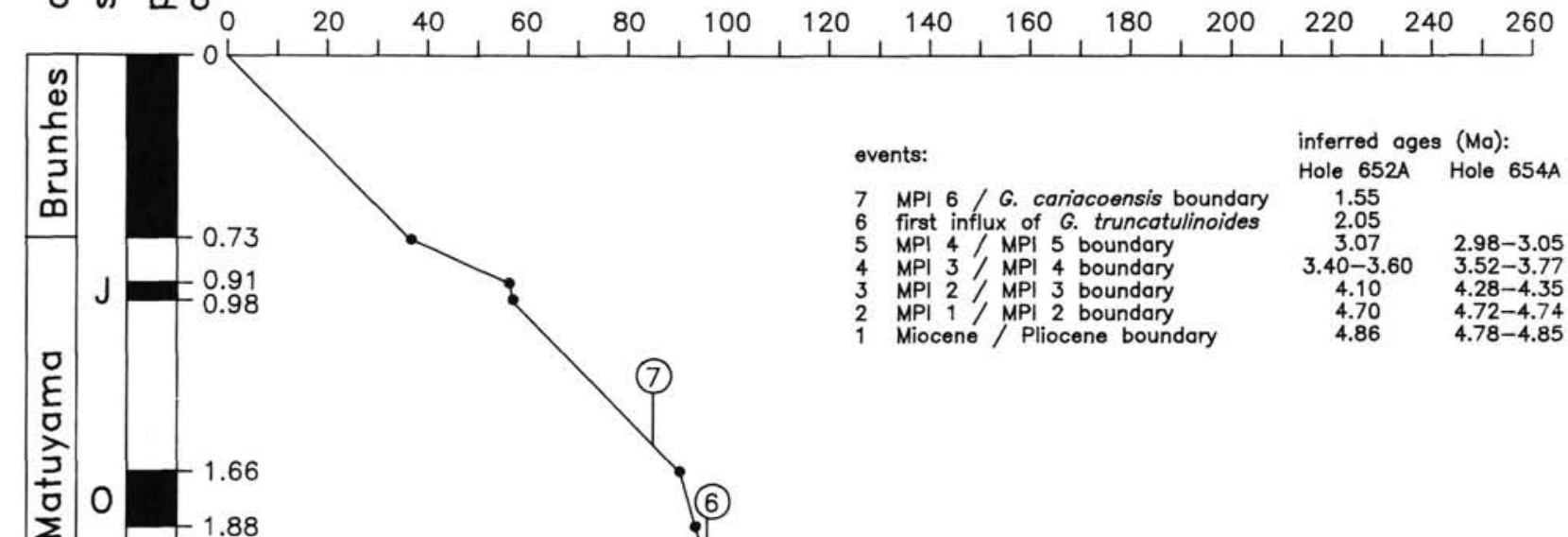